\author{
KAMILA Plis, JOANNA STOJAK \\ Instytut Biologii Ssaków PAN \\ Stoczek 1, 17-230 Białowieża \\ E-mail: kplis@ibs.bialowieza.pl
}

\title{
PROCES DOMESTYKACJI PSA: PRÓBA ROZWIKŁANIA ZAGADKI UDOMOWIENIA GATUNKU
}

\section{WSTEP}

Udomowienie stanowi niezwykle ważny proces, leżacy u podstawy znanego nam obecnie świata. Nie istnieje żaden współcześnie wykorzystywany przez człowieka gatunek zwierzęcia lub rośliny, który w przeszłości nie podlegałby domestykacji. Dokładne opisanie przebiegu tego skomplikowanego procesu wciaż jest niemożliwe, ale bezsprzecznie wiadomo, że najstarszym udomowionym gatunkiem był pies (Canis lupus familiaris). Poczatkowo człowiek nie szukał $\mathrm{w}$ psie towarzysza, ale partnera, którego zadaniem była pomoc w polowaniu i wypasie zwierzat hodowlanych oraz ochrona domostw. Kiedy człowiek i przodek współczesnego psa spotkali się po raz pierwszy? Nauka nadal nie umie jednoznacznie odpowiedzieć na to pytanie, a czas i miejsce jego domestykacji nadal pozostaja nieznane (OvoDOV i współaut. 2011, GERMONPRÉ i współaut. 2012, LARSON i współaut. 2012, MOREY 2014).

Celem niniejszego artykułu jest zaprezentowanie obecnego stanu wiedzy dotyczacej wciąż niepoznanej historii udomowienia psa i przedstawienie prawdopodobnego przebiegu procesu domestykacji gatunku.

\section{PRAWDOPODOBNE CENTRA UDOMOWIENIA PSA}

Lokalizacja centrów udomowienia psa wzbudza wśród naukowców sporo kontrowersji. Jedne badania zakładaja, że istniało tylko jedno centrum udomowienia psa, inne sugeruja, że psa udomowiono dwa razy. Mimo wielu badań, kwestia ta nie została dotąd jednoznacznie rozwiazana. W literaturze znaleźć można wiele prac próbujących określić gdzie i kiedy pies został udomowiony, w tym artykule skupiono się jedynie na najbardziej popularnych. Opisane poniżej hipotezy nie wykluczaja się wzajemnie i wszystkie moga być prawdziwe. Aby jednak umożliwić czytelnikom zapoznanie się $z$ pozostałymi, nieopisanymi szerzej w artykule teoriami, wymieniono je w Tabeli 1. Pokazuje ona również jak znaczne sa rozbieżności pomiędzy badaniami, niektóre różniące się nawet o rzad wielkości od pozostałych [wg VILÀ i współaut. (1997) psa udomowiono 135 tysięcy lat temu!].

Najbardziej popularna teoria jest pochodzenie Canis lupus familiaris $\mathrm{z}$ obszarów Azji, które stanowia główny ośrodek występowania pierwotnych ras tego gatunku. Podażajac tym tropem, zespół Roberta Wayne’a przeprowadził badania, które ujawniły, że światowe populacje psów charakteryzuja się profilem zmienności genetycznej, prowadzącej bezpośrednio do wilków z Bliskiego Wschodu (rejon Żyznego Półksiężyca) (VoNHOLDT i współaut. 2010). W sprzeczności z tym pozostaja wyniki innego zespołu, który sugeruje, że ośrodek udomowienia psa umiejscowiony w Azji Wschodniej jest watpliwy i jako bardziej prawdopodobny proponuje obszary Afryki wschodniej, cechujacy się największą zmiennościa genetyczna w populacji dziko żyjących psów (BOYKO i współaut. 2009).

Dopiero badania genomowe odwróciły uwage naukowców od obszarów południowych. THALMANN i współautorzy (2013) opublikowali badania, które sugeruja, że udomowienie psa mogło mieć miejsce w 
Tabela 1. Dotychczasowy stan wiedzy dotyczacy przypuszczalnego czasu i miejsca udomowienia psa Canislupus familiaris.

\begin{tabular}{lll}
\hline $\begin{array}{l}\text { Czas udomowienia } \\
{[\text { lat temu }]}\end{array}$ & Miejsce udomowienia & Literatura \\
\hline 135.000 & - & VILÀ i współaut. 1997 \\
$60.000-20.000^{*}$ & Azja Wschodnia, Eurazja Zachodnia & FRANTZ i współaut. 2016 \\
$40.000-27.000$ & Azja & SKOGLUND i współaut. 2015 \\
$40.000-20.000$ & Europa & BOTIGUÉ i współaut. 2017 \\
40.000 & Azja wschodnia & SAVOLAINEN i współaut. 2002 \\
$32.100-18.800$ & Europa & THALMANN i współaut. 2013 \\
$31.000-12.000$ & Środkowy Wschód, Europa & VonHOLDT i współaut. 2010 \\
15.000 & Azja wschodnia & Larson i współaut. 2012 \\
\hline
\end{tabular}

* Szacunkowy czas rozdziału psa od wilka; podział pomiędzy linią wschodnią a zachodnia psa nastapił 14.0006.400 lat temu.

paleolitycznej Europie. Analiza mutacji pojedynczych nukleotydów (ang. single nucleotide polymorphism, SNP) popiera tę teorię (VONHOLDT i współaut. 2010). Z kolei wyniki skanowania kompletnego genomu mitochondrialnego współczesnych psów sugeruja, że udomowienie nastapiło $\mathrm{w}$ południowej części Chin (około 16 tysięcy lat temu) (DRUZHKOVA i współaut. 2013).

Najnowsze opublikowane dane uzyskane $\mathrm{w}$ badaniach mitochondrialnego DNA (mtDNA) wskazują występowanie dwóch miejsc udomowienia gatunku, zlokalizowanych we wschodniej i zachodniej Eurazji (FRANTZ i współaut. 2016). Oznacza to, że starożytne psy azjatyckie wywodza się od udomowionych wilków azjatyckich (co najmniej 12,5 tysięcy lat temu), a europejskie paleolityczne psy pochodza $z$ niezależnych procesów udomowień wilków europejskich (sprzed co najmniej 15 tysięcy lat). Połączenie pul genetycznych nastapiło około 6,4 tysięcy lat temu, gdy psy azjatyckie zostały przetransportowane przez ludzi do Europy (FRANTZ i współaut. 2016). Odkrycie to tłumaczyłoby wyniki wcześniejszych badań, wskazujących tylko jedno centrum udomowienia.

\section{ROLA PSA NA WCZESNYM ETAPIE HISTORII UDOMOWIENIA}

Przyczyny, które doprowadziły do rozpoczęcia procesu udomowienia również wzbudzaja wśród badaczy kontrowersje i opublikowano na ten temat wiele teorii. Historia relacji człowieka $z$ psem sięga epoki kamienia łupanego. Pierwotna hipoteza zakładała, że człowiek zabierał do swojego stada szczenięta wilków i odchowywał je tak, że stawały się częścia jego grupy. Obecnie uwa- ża się, że wilki samodzielnie zbliżyły się do człowieka, podażając za nim i żerując na pozostawionych przez niego resztkach mięsa, głównie mamutów (BUDIANSKY 1999). Komensalizm był sposobem na łatwe zdobycie białka (FREEDMAN i współaut. 2016).

Początkowo żerujace na resztkach upolowanych zwierzat i szwendające się $\mathrm{w}$ bliskiej odległości ludzi wilki wzbudzały zapewne podejrzliwość, człowiek szybko jednak zauważył, że wzajemna relacja może być dla niego korzystna (FREEDMAN i współaut. 2016). Aby jednak zdobyć zaufanie dzikiego zwierzęcia i zmusić je do współpracy, należało zapewnić mu odpowiednie, zadowalajace je warunki. Nisze pokarmowe obu gatunków pokrywały się, ponieważ ludzie i wilki polowali na te same zwierzęta. Współpraca i życie w symbiozie mogły ułatwić obu stronom pozyskanie pokarmu. Wilk potrafił wytrwale gonić upatrzona ofiare, aż do jej wyczerpania, natomiast człowiek, posługujacy się kamiennymi ostrymi narzędziami, mógł szybko i skutecznie uśmiercić zwierzę. Współpraca $z$ oswajanymi wilkami pozwalała ludziom upolować jednocześnie kilka mamutów, zamiast jednego, jak bywało wcześniej. Zarówno wilk, jak i człowiek zużywali przy tym znacznie mniej energii, osiagając jednocześnie większy sukces. Wilk dodatkowo zyskiwał stałe źródło pożywienia i $z$ czasem opiekę oraz bezpieczne schronienie (FREEDMAN i współaut. 2016).

Psa udomowili ludzie zajmujący się zbieractwem i łowiectwem, zatem wykorzystywany był jako pomocnik $\mathrm{w}$ polowaniach, pomagał $\mathrm{w}$ transporcie dobytku i ciagnał sanie $z$ pasażerami. Stanowił skuteczną ochronę przed dzikimi zwierzętami i ludźmi $z$ innych plemion. Wraz z osiedlaniem się człowieka i 
zmianami wprowadzonymi podczas rewolucji neolitycznej, pies zaczyna być wykorzystywany do pilnowania stad zwierzact hodowlanych i jako strażnik domostw. Badania archeologiczne pokazują jednak, że oprócz swoich funkcji użytkowych, pies mógł być także przyjacielem człowieka (MOREY 2006).

Podczas wykopalisk prowadzonych w Izraelu na stanowisku niedaleko Ein Mallaha odkryto pozostałości po kulturze natufijskiej. Wiek stanowiska archeologicznego oszacowano na IX tysiaclecie p. n. e. W jednym $z$ odkrytych grobów znaleziono najprawdopodobniej dowód na głęboka przyjaźń pomiędzy człowiekiem a jego psem - osobnik nieznanej płci został pochowany wraz ze szczeniakiem, ułożonym blisko głowy zmarłego, $z$ jego dłonia na brzuchu zwierzęcia (DAVIS i VALLA 1978). Tak bliska relacja mogła świadczyć o bardzo emocjonalnym stosunku właściciela do psa. Wydaje się, że nie jest to odosobniony przypadek. Pierwsze zapiski dotyczące psów i przedstawianie ich wizerunków pojawiają się w Mezopotamii; w Persji wierzono, że psy sa strażnikami wejścia do świata umarłych, a Asyryjczycy tuż przed śmiercią spoglądali w oczy tego zwierzęcia (MOREY 2006, MONKIEWICZ i współaut. 2011).

Domestykacja psa była procesem długim i skomplikowanym, opartym na ciagłej ewolucji relacji pies-człowiek, wykształcajacej wraz $z$ upływem czasu szereg zmian morfologicznych i behawioralnych (SERPELL 2016a). Analiza tych zmian stanowi podstawę badań dążących do ostatecznego opisania jak, gdzie i kiedy udomowiono psa. W dwóch kolejnych podrozdziałach umieszczono charakterystyke tych zmian.

\section{CECHY MORFOLOGICZNE}

Udomowienie było procesem stopniowym, w trakcie którego kolejne pokolenia wilków stopniowo dostosowywały się do warunków życia blisko ludzi. Adaptacje do nowego rodzaju pokarmu oraz zależność od człowieka w jego zdobywaniu skutkowały szeregiem zmian w morfologii zwierząt. Wyróżnić można trzy metody analizujące ewolucję cech morfologicznych w trakcie procesu udomowienia: klasyczna morfologia i opis sekwencji zaobserwowanych w niej zmian (OLSEN i OLSEN 1977), klasyczna morfometria, mierzaca wielkości i proporcje zmian (MOREY 1986, WAYNE 1986) oraz najnowsza morfometria geometryczna (PIONNIER-CAPITAN 2010). Wszystkie te metody umożliwiaja m.in. opis obiektywnych zmian zaobserwowanych pomiędzy dwoma podgatunkami oraz ustalenie czy analizowana czaszka należała do wilka czy psa.
Wnikliwa analiza cech morfologicznych ujawniła, że w trakcie domestykacji u pierwotnych psów zmniejszyły się rozmiar ciała oraz wielkość czaszki (BoudADI-MALIGNE i EscARguel 2014, CLUTTON-BROCK 2016). Skarłowacenie jest cechą charakterystyczna na poczatkowym etapie udomowienia u wielu gatunków ssaków (CLUTTON-BROCK 1999) i pozwala na sprawne funkcjonowanie organizmu w okresach niedoboru pokarmu. Dodatkowo, TCHERNOV i HORWITZ (1991) zasugerowali, że zarówno zmniejszenie rozmiarów ciała, jak i mniejszy rozmiar szczeniat były zwiąane $z$ przyśpieszonym dojrzewaniem, zwiększoną liczbą potomstwa i skróceniem okresu pomiędzy pokoleniami.

Również pysk zwierząt podlegał istotnym zmianom: stał się krótszy i szerszy, co w konsekwencji doprowadziło do agregacji i zmiany położenia zębów (CLUTTON-BROCK 1963, BENECKE 1987, MOREY 1992). Współczesne psy maja stosunkowo mniejsze zęby niż ich dzicy przodkowie, co widoczne jest nawet w przypadku największych ras psów, takich jak dog niemiecki. Zmianie uległa także żuchwa, która w porównaniu do wilka stała się bardziej zakrzywiona. Doprowadziło to do zwiększenia się kąta oczodołowego oraz zaokraglenia się gałek ocznych i ukierunkowania ich do przodu (STOCKHAUS 1965, BENECKE 1987).

Analizy materiału kopalnego sugeruja także istotne zmiany w obrębie innych elementów wyglądu zewnętrznego psów, np. w kolorze sierści. TRUT i współaut. (2009) testowali na lisach (Vulpes vulpes) jak kontrolowany rozród może wpływać na fenotyp udomowionych osobników. Ich badania wykazały, że cechy takie jak białe plamy, oklapnięte uszy czy zakręcony ogon moga stanowić morfologiczne markery udomowienia.

Z kolei badania asocjacyjne całego genomu (ang. genome-wide association study, GWAS) potwierdziły, że adaptacje wyrażone zmianami w morfologii zwierzęcia przekładają się na zmiany w obrębie genów kodujących określony parametr wyglądu, takich jak budowa szkieletu, kolor, długość i struktura sierści czy pomarszczona skóra (VAN DEN BERG 2016). PARKER i współaut. (2009) wykazali za pomoca tej metody, że posiadanie krótkich łap, charakterystycznych dla ras takich jak jamnik, corgi czy basset, zwiazane jest $z$ ekspresja retrogenu kodujacego jeden $z$ czynników wzrostu fibroblastów.

\section{CECHY BEHAWIORALNE}

Śledząc historię udomowienia psa można odnieść wrażenie, że na początku zachowanie zwierząt odgrywało znacznie ważniejsza 
rolę niż ich wygląd. Na wczesnym etapie relacji człowiek-pies, domestykacji częściej podlegały osobniki, które charakteryzował obniżony poziom strachu i agresji oraz większa ciekawość (VAN DEN BERG 2016). Badania GÁCSI i współaut. (2009), porównujące reakcje (m.in. poziom agresji, chęć współpracy) na polecenia człowieka wilków i psów w różnym wieku zdaja się to potwierdzać, jednak badacze podkreślają, że nadal stanowi to tylko jeden $z$ wielu prawdopodobnych czynników. Niewątpliwie przodek współczesnego psa musiał wykształcić zachowania, które efektywnie zwracały na niego uwage człowieka i które zyskiwały jego uznanie.

Pies, jako jedno $z$ niewielu zwierząt, wchodzi w socjalne interakcje nie tylko $Z$ innymi osobnikami swojego gatunku, ale co najważniejsze, sprawnie komunikuje się $Z$ ludźmi (MIKLÓsi 2007, BRADSHAW i ROONEY 2016). W komunikacji psy wykorzystuja trzy typy sygnałów: wizualne (obserwacja ludzkiej twarzy lub gestów, machanie ogonem), głosowe (reaguja na polecenia człowieka, szczekaja) oraz zapachowe (maja ekstremalnie dobry węch) (MIKLÓsI 2007, NAGASAWA i współaut. 2011, BRADSHAW i ROONEY 2016). Poprzez obserwację zachowań człowieka psy potrafia odczytać intencje oraz odróżnić, które $z$ naszych zachowań są celowe, a które przypadkowe. $Z$ kolei swoim zachowaniem sygnalizuja nastrój, potrzeby i nastawienie, machając ogonem, gdy sa zadowolone lub szczerzac groźnie zęby i jeżąc sierść w momentach zagrożenia/złości.

W toku badań zauważono również, że psy sa zwierzętami bardziej wokalizujacymi niż wilki. Wilki szczekają bardzo rzadko, ich komunikacja opiera się głównie na przeciągłym wyciu, docierajacym na znaczne odległości (SCHASSBURGER 1987, FEDDERSEN-PETERSEN 2000). Psy z kolei wykształciły różne częstotliwości szczekania, zależne od kontekstu i nastroju. Najprawdopodobniej jest to wynikiem selekcji człowieka, który wybierał szczekajace osobniki, doskonale sprawdzające się jako stróże domostw i zwierząt hodowlanych, odpowiednio wcześniej sygnalizujące zbliżanie się drapieżników lub obcych (BRADSHAW i ROONEY 2016). Silna selekcja pod katem określonego zachowania była także istotnym elementem wpływajacym na różnicowanie się grup psów. Różne aspekty dziedzicznych zachowań wilka były wykorzystywane w celu utworzenia najlepszych możliwych „typów” pełniacych rolę jako psy pasterskie, ochronne, zaprzęgowe czy myśliwskie (VAN DER BERG 2016).

Pionierskie badania SCOTTA i FULLERA (1965) nad różnicami w zachowaniu poszczególnych ras psów oraz dziedzicznościa psich zachowań potwierdziły, że behawior, podobnie jak cechy morfologicznie, jest przekazywany w genomie. Potwierdza to również wymieniona $\mathrm{w}$ poprzednim rozdziale analiza GWAS. Przy jej użyciu DoDMAN i współaut. (2010) przeanalizowali genomy 90 dobermanów wykazujących obsesyjno-kompulsywne zachowania i porównali je do 70 zdrowych psów. Badania wykazały, że niespokojne zachowania zwierzat mogły być zwiąane $z$ punktowa mutacja odnaleziona na 7 chromosomie. Dzięki temu, że cechy charakteru (także te negatywne) podlegały dziedziczeniu, człowiek mógł wyselekcjonować w trakcie udomowienia psy wykazujace zachowania pożądane, przydatne w zależności od funkcji pełnionej przez zwierzę. Oprócz szczekania, były to m.in.: poziom aktywności, obrona terytorium czy poziom agresji (DUFFY i współaut. 2008, HART i HART 2016).

Psy jako jedyny gatunek wykazuja zachowania na wzór ludzkich (ang. human-like social behavior), potrafiacc nie tylko rozpoznać emocje właściciela, ale same maja zdolność do odczuwania empatii czy poczucia winy (RANGE i VIRÁNYI 2016). Wspomnieć należy również ich nadzwyczajna zdolność do szybkiego uczenia się poprzez obserwację ludzi i/lub innych psów (SERPEll i HSU 2005). Wczesne psy $z$ epoki kamienia łupanego posiadały predyspozycje do nawiąania kontaktu z człowiekiem, jednak zdolność do szybkiej adaptacji i uczenia się umożliwiły im utrzymanie stałego zainteresowania ludzi (RANGe i VIRÁNYI 2016). Pomimo opisanych adaptacji i dużej plastyczności, właściciele nie zawsze umożliwiaja zwierzętom spełnienie potrzeb specyficznych gatunkowo. Powoduje to u psów różne problemy behawioralne, takie jak agresję czy choroby. Mimo ponad tysiacca lat silnej presji człowieka i nieustannej adaptacji psów do zmieniajacych się warunków życia, gatunek ten nadal podlega zmianom. Zmiany te jednak już dawno przestały mieć na celu użytkowość gatunku.

\section{PODZIAE NA GRUPY, TYPY I RASY - INGERENCJA CZEOWIEKA W WYGLĄD PSA}

Jak już wspomniano, bardzo długo wygląd psa pozostawał kwestia mniej istotna, ważniejsza była zdolność do pełnienia funkcji zaplanowanych dla niego przez człowieka pierwotnego. Badania archeologiczne prowadzone w kilku europejskich lokalizacjach, których wiek oszacowano na okres górnego paleolitu (40-13 tysięcy lat p.n.e.) ujawniły, że w epoce kamienia łupanego zróżnicowanie psów ograniczało się do wielkości ciała zwierząt (GERMONPRÉ i współaut. 2009, PIONNIER-CAPITAN i współaut. 2011). 
Małe psy (wysokość poniżej $45 \mathrm{~cm}$ ) zostały zidentyfikowane m.in. w Niemczech (Oberkassel, Teufelsbrucke i Oelknitz), Szwajcarii (Hauterive-Champreveyres), Francji (Saint-Thibaud-de-Couz, Pontd'Ambon) i Hiszpanii (Erralia). Wiek tych skamieniałości oszacowano na 15-12,3 tysięcy lat temu. Psy średniej wielkości (wysokość między 45 a $60 \mathrm{~cm}$ ) zostały zidentyfikowane w kilku miejscach na Bliskim Wschodzie (Tell Mureybet w Syrii, EinMallaha w Izraelu, jaskinia Pelagawra w Iraku), a ich wiek oszacowano na 15,5-11 tysięcy lat. Największe psy (wysokość powyżej $60 \mathrm{~cm}$ ) zamieszkiwały tereny współczesnych Niemiec (Kniegrotte), Rosji (Eliseevichi I) i Ukrainy (Mezin) około 17-13 tysięcy lat temu (GERMONPRÉ i współaut. 2009, PIONNIER-CAPITAN i współaut. 2011).

W późniejszych czasach zaczęto dzielić psy na tzw. "typy” na podstawie pełnionych przez nie funkcji (PARKER i współaut. 2004, VONHOLDT i współaut. 2010). Podział ten utrzymywał się bardzo długo, a tak bardzo popularne obecnie pojęcie "rasy” narodziło się dopiero w XVIII w. (WILCOX i WALKOWICZ 1995, De VITO 2005, MonkIEWICZ i współaut. 2011). Wiek najstarszych psich ras nie przekracza 500 lat, a najwięcej $z$ nich powstało zaledwie 150 lat temu.

Początkowo tworzono rasy przez łaczenie wybranych typów psów, w celu uzyskania określonych cech fenotypowych i/lub użytkowych. W ten sposób potrzebne $z$ punktu widzenia człowieka cechy zostały utrwalone, a cechy zbędne szybko wyeliminowane. Zmiany te nie zawsze były korzystne dla psów, utrudniając im nawet prawidłowe funkcjonowanie. Na przykład psy peruwiańskie nie sa pokryte ochronna sierścia, przez co sa bardzo wrażliwe na zimno i promieniowanie słoneczne (grożą im nawet poparzenia i powinny być smarowane filtrami przeciwsłonecznymi). Zaprojektowane do walki buldogi maja czaszki o skróconym pysku, co skutkuje fatalnym zgryzem i poważnymi utrudnieniami w oddychaniu (WILCOX i WALKOWICZ 1995, DE VITO 2005, MONKIEWICZ i współaut. 2011). Wśród ras psów można wyróżnić nawet tak zwane „rasy narodowe”. W tej dziedzinie prym wiedzie Wielka Brytania, która pochwalić się może m.in. 27 rasami terierów. W Polsce stworzono pięć ras narodowych: polskiego owczarka nizinnego, polskiego owczarka podhalańskiego, ogara polskiego, gończego polskiego i charta polskiego (MonkIEwICZ i współaut. 2011). Rejestracja ras i ścisła selekcja cech morfologicznych poszczególnych psów rozpoczęła się dopiero $\mathrm{w}$ momencie utworzenia Związków Kynologicznych. Co ciekawe, porównanie wyglądu ras sprzed stu lat i z czasów współczesnych pokazuje, że wygląd rasy podlega ciagłym manipulacjom. Dla przykładu dawniej owczarka niemieckiego charakteryzowała kwadratowa sylwetka, dziś psy z tej rasy mają długi tułów i nisko osadzony zad (MONKIEWICZ i współaut. 2011).

Zastanawiające było jednak, czy preferencje człowieka obowiazujace w epoce kamienia łupanego przełożyły się na wygląd współczesnych psów. LARSON i współautorzy (2012) postanowili to sprawdzić, analizując zmienność markerów SNP u psów z okresu paleolitu i współczesnych. Uzyskane wyniki okazały się zaskakujace. Pomimo wyraźnego zróżnicowania wielkości ciała, wśród wczesnych psów górnego paleolitu (np. małe, średnie i duże psy znalezione w Svaerdborgu) nie przełożyło się to w żadnym stopniu na pojawienie się i wygląd współczesnych ras. Zatem, jaki proces doprowadził do tak niezwykłych zmian i zupełnego rozdzielenia się typów i ras psów? Istnieje wiele teorii na ten temat, $z$ których najpopularniejsza podaje, że pierwotne populacje ludzkie o charakterze łowiecko-zbierackim wymuszały procesy migracji, co doprowadziło do rozprzestrzenienia się psów na znacznym terenie (DRISCOLL i współaut. 2009, DREGER i współaut. 2016). Wzrost populacji ludzkiej i utworzenie się sieci handlowych doprowadziły jednak do ponownego połaczenia się odizolowanych od siebie grup osadniczych, a tym samym ponownego wymieszania się puli genetycznych różnych populacji psów (LARSON i współaut. 2012). W ten sposób wszystkie stworzone przez ostatnie 500 lat rasy psów powstały $z$ jednorodnej puli genów.

Nie należy również zapominać, że zmiany w traktowaniu i postrzeganiu psa, zachodzace przez tysiąclecia, doprowadziły do wymarcia wielu popularnych kiedyś form/typów/ grup tego gatunku. Doskonałe podsumowanie tego procesu zaprezentowali PARKER i współaut. (2004), dzielac psy na trzy grupy.

Pierwsza grupa były tzw. psy wymarłe, które cenione były ze względu na swoja przydatność. Ich wizerunki były przedstawiane wielokrotnie w starożytnej sztuce. Jak wskazuje nazwa grupy, psy nie przetrwały do czasów współczesnych. Powodem było krzyżowanie się $z$ psami nowożytnymi oraz, $z$ czasem, utrata zapotrzebowania na pelnione przez nie funkcje. Do psów wymarłym zaliczyć można m.in. psa Chiribaya (pies pasterski $z$ Ameryki Południowej $z$ okresu przed przybyciem Europejczyków), Molossera (rasa masywnych psów wywodząca się ze starożytnej Grecji, wykorzystywane m.in. do walk $\mathrm{i}$ w trakcie wojen) czy Kuri (polinezyjska rasa psa, źródło mięsa i skór).

Druga grupa sa tzw. psy prymitywne, czyli rodowite dla miejsca lub regionu. Mimo krzyżowania $z$ psami przywiezionymi $z$ in- 
nych terenów, cechy psów prymitywnych pozostały niezmienione. Oznacza to, że grupa ta wyewoluowała bez istotnej ingerencji człowieka. Psy prymitywne nadal zamieszkują różne części świata (np. śsiewający pies $z$ Nowej Gwinei, Dingo w Australii).

Ostatnia grupe nazwano psami antycznymi lub pierwotnymi, ponieważ odnosi się do psów, których profil genetyczny jest najbardziej zbliżony do nieudomowionych psowatych, a w szczególności do wilka szarego (Canis lupus). Mimo rozbieżności w przypisaniu poszczególnych ras psów do tej grupy, za reprezentantów psów antycznych uznaje się charta afgańskiego, malamuta, chow-chow, samojeda i husky syberyjskiego (PARKER i współaut. 2004, VONHOLDT i współaut. 2010).

Zagadnienia opisane $\mathrm{w}$ tym rozdziale nasuwaja pytanie, czy rzeczywiście współczesne postrzeganie psa jest tak bardzo różne od tego jak postrzegano go $\mathrm{w}$ epoce kamienia łupanego i czy udomowienie tego gatunku niosło za soba jedynie obustronne korzyści.

\section{RELACJA PIES-CZŁOWIEK WE WSPÓŁCZESNYM ŚWIECIE}

Więź między psem a człowiekiem może być wyjątkowa. Potwierdzają to badania archeologiczne (DAVIS i VALLA 1978, MOREY 2006) oraz sposób w jaki współcześnie ludzie traktuja psy (ZAWISTOWSKI i REID 2016). Nawet przysłowia twierdza, że „pies jest najlepszym przyjacielem człowieka”. Dzięki wyjątkowym zdolnościom poznawczym psy znajduja zastosowanie jako cierpliwi i oddani opiekunowie osób niepełnosprawnych i starszych oraz w terapiach (ang. human-animal interactions). Uważa się, że dzieci wychowywane w obecności psa sa radosniejsze, bardziej otwarte i łatwiej nawiazuja kontakty (HART i YAMAMOTO 2016, SERPELL 2016b). NAGASAWA i współaut. (2015) wykazali, że długi kontakt wzrokowy pomiędzy człowiekiem a psem powoduje $u$ obu stron zwiększenie produkcji oksytocyny, nazywanej także hormonem szczęścia. Badacze sugeruja nawet, że być może mechanizm ten przyczynił się do udomowienia psa.

Pies trzymany jest w wielu domach jako przyjaciel i towarzysz, często jednak ludzie nie zapewniają im warunków specyficznych gatunkowo. Skutkuje to pojawieniem się u zwierząt podwyższonej agresji, wyższym poziomem odczuwanego stresu czy zaawansowaną otyłościa (HUBRECHT i współaut. 2016).

Antropomorfizacja psa charakterystyczna jest jednak tylko dla "cywilizacji zachodu" (PERIN 1981). W wielu rejonach świata relacja pies-człowiek przedstawia się inaczej. Psy postrzegane sa przez pryzmat swojej przy- datności i pełnionej funkcji. Pies nie jest zatem przyjacielem, ale swoistym robotnikiem, wykorzystywanym do polowań, pilnowania zwierząt hodowlanych, stróżowania, a nawet wyścigów (LORD i współaut. 2016). W Azji stanowi źródło pokarmu (SERPELL 2016b). Brak skutecznego zarzadzania populacjami bezpańskich psów w wielu krajach skutkuje problemem $z$ agresywnymi, wałęsajacymi się watahami (tzw. psów free-ranging), traktowanymi jak szkodniki, stanowiącymi zagrożenie dla ludzi i dzikiej zwierzyny, na która poluja (np. zajace, sarny). Psy stanowia także rezerwuar wielu niebezpiecznych chorób, którymi moga zarazić człowieka (m.in. wścieklizna, świerzb, nicienie, grzybica czy toksokaroza). KALETA (2015) podaje, że w Indiach 97\% przypadków zarażenia ludzi wirusem wścieklizny nastapiło w wyniku transferu od psów. W Polsce, mimo iż szczepienia przeciw wściekliźnie są obowiązkowe, wciąz nie wszyscy właściciele dostosowuja się do tych wymogów. Oznacza to, że mimo iż bilans udomowienia dla obu stron wydaje się być dodatni, nie należy zapominać o kosztach tego procesu, poniesionych i nadal ponoszonych zarówno przez psy, jak i człowieka.

\section{PODSUMOWANIE}

Początkowo przodkowie psów konkurowali $z$ człowiekiem o zasoby pokarmowe, następnie ludzie wykorzystywali je do polowań, ochrony czy pilnowania zwierzat hodowlanych, a dziśs człowiek tworzy rasy, które często zamiast funkcjonalnością charakteryzują się karykaturalnymi i niepraktycznymi cechami morfologicznymi. Jednak w każdym psie nadal drzemia geny jego przodków i pierwotnych wilków, które kiedyś po raz pierwszy zbliżyły się do człowieka. Analizy porównawcze genomów psa i wilka ujawniają liczne różnice, przekładające się na morfologię, behawior czy podatność na choroby. To właśnie kombinacja tych zmian, nagromadzonych przez ostatnie tysiaclecia, doprowadziła do powstania Canis lupus familiaris, psa jakiego dziś znamy.

Pomimo licznych badań, zagadka udomowienia psa nadal nie została rozwiazana. Zaprezentowane w tekście hipotezy ujawniaja jak kontrowersyjny jest to temat oraz jak wiele rozbieżności pojawia się w trakcie prób jego rozwikłania. Być może miejsce, czas i przebieg długiego i skomplikowanego procesu domestykacji psa nigdy nie zostana poznane (OvODOV i współaut. 2011, GERMONPRÉ i współaut. 2012, LARSON i współaut. 2012, MOREY 2014). Niewatpliwie jednak zaprezentowany przegląd systematyzuje obecnie dostępna wiedze na ten temat oraz pokazuje, że mimo braku jednej ostatecznej 
hipotezy wyjaśniającej opisywany proces, postawione przez badaczy teorie nie wykluczają się wzajemnie i tworza coraz pełniejszy i bardziej prawdopodobny obraz domestykacji zwierzęcia najwcześniej udomowionego przez człowieka. W artykule pokazano też jak silna może być presja człowieka na powstawanie nowych podgatunków/gatunków.

\section{Streszczenie}

Pies jest najstarszym zwierzęciem udomowionym przez człowieka, jednak przegląd literatury udowadnia, że czas i miejsce jego domestykacji nadal pozostaja niejasne. Celem niniejszego artykułu jest przedstawienie, jak prawdopodobnie mógł przebiegać proces udomowienia psa oraz zaprezentowanie jego przyczyn i skutków.

\section{LITERATURA}

BENECKE N., 1987. Studies on early dog remains from Northern Europe. J. Archaeol. Sci. 14, 31-49.

Botigué L., Song S., Scheu A., Gopalan S., PenDLeton A. L., OetJens M., TARAVElla A. M. i współaut., 2017. Ancient European dog genomes reveal continuity since the Early Neolithic. Nature Comm. 8, 16082.

BoudAdi-Maligne M., Escarguel G., 2014. A biometric re-evaluation of recent claims for Early Upper Palaeolithic wolf domestication in Eurasia. J. Archaeol. Sci. 45, 80-89.

BOYKO A. R., BOYKO R. H., BOYKO C. M., PARKeR H. G., Castelhano M., CoReyl., DegenHARDT J. i współaut., 2009. Complex population structure in African village dogs and its implications for inferring dog domestication history. Proc. Natl. Acad. Sci. USA 106, 1390313908.

BRADSHAW J., RoONEY N., 2016. Dog social behavior and communication. [W:] The domestic dog. Its evolution, behavior and interactions with people. SERPELL J. (red.). Cambridge University Press, Cambridge, 134-159.

BUDIANSKY S., 1999. The covenant of the wild: why animals chose domestication. Yale University Press, New Haven.

CLUTTON-BROCK J., 1963. The origins of the dog. [W:] Science in Archaeology: a Comprehensive survey of progress and research. BROTHWELL D., HigGs E. (red.). Praeger, Nowy Jork, 303309.

ClutTon-Brock J., 1999. A natural history of domesticated mammals. Cambridge University Press, Cambridge.

ClutTon-BRock J., 2016. Origins of the dog: the archaeological evidence. [W:] The domestic dog. Its evolution, behavior and interactions with people. SERPELL J. (red.). Cambridge University Press, Cambridge, 7-21.

DAVIS S., VAlla F. R., 1978. Evidence for domestication of the dog 12,000 years ago in the Natufian of Israel. Nature 276, 608-610.

DE VITO D., 2005. World atlas of dog breeds. T.F.H. Publications, Neptune City.

Dodman N. H., Karlsson E. K., MoOn-Fanelli A., GaldZicka M., Perloski M., Shuster L., LindBLAD-TOH K., GINNS E. I., 2010. A canine chromosome 7 locus confers compulsive disorder susceptibility. Mol. Psychiat. 15, 8-10.

Dreger D. L., Davis B. W., COCCO R., SECHI S., Di Cerbo A., Parker H. G., Polli M., MarelLI S. P., CREPAldi P., OSTRANDER E. A., 2016. Commonalities in development of pure breeds and population isolates revealed in the genome of the Sardinian Fonni's dog. Genetics 204, 737-755.

Driscoll C. A., MACDonald D. W., O’Brien S. J., 2009. From wild animals to domestic pets, an evolutionary view of domestication. Proc. Natl. Acad. Sci. 106, 9971-9978.

DruzhKova A. S., ThalmanN O., TRIfonov V. A., LEONARD J. A., VOROBIEVA N. V., OVODOV N. D., GRAPHODATSKY A. S., WAYNE R. K., 2013. Ancient DNA analysis affirms the canid from Altai as a primitive dog. PLoS One 8, e 57754.

Duffy D. L., Hsu Y., SerPell J. A., 2008. Breed differences in canine aggression. Appl. Anim. Behav. Sci. 114, 441-460.

FEDDERSEN-PETERSEN D. U., 2000. Vocalization of European wolves (Canis lupus lupus L.) and various dog breeds (Canis lupus familiaris). Arch. Tierzucht 43, 387-397.

Frantz L. A. F., MULLIN V. E., PIONNIER-CAPITAN M., Lebrasseur O., Ollivier M., PerRi A., LINDERHOLM A. i współaut., 2016. Genomic and archaeological evidence suggests a dual origin of domestic dogs. Science 352, 12281231.

Freedman A. H., LOHMUelleR K. E., WAYNe R. K., 2016. Evolutionary history, selective sweeps, and deleterious variation in the dog. Ann. Rev. Ecol. Evol. Syst. 47, 73-96.

GÁcsi M., GYÖRI B., VIRÁNYI Z., KUBINYI E., RANGE F., BELÉNYI B., MIKLÓSI A., 2009. Explaining dog wolf differences in utilizing human pointing gestures: selection for synergistic shifts in the development of some social skills. PLoS One 4, e6584.

GERMONPRÉ M., SABlin M. V., STEVEns R. E., Hedges R. E. M., Hofreiter M., Stiller M., DESPRÉ V. R., 2009. Fossil dogs and wolves from Palaeolithic sites in Belgium, the Ukraine and Russia: osteometry, ancient DNA and stable isotopes. J. Archaeol. Sci. 36, 473-490.

GERMONPRÉ M., LÁZNICKOVÁ-GALETOVÁ M., SABLIN M. V., 2012. Palaeolithic dog skulls at the Gravettian Predmostí site, the Czech Republic. J. Archaeol. Sci. 39, 184-202.

HART B. L., HART L. A., 2016. Breed and gender differences in dog behavior. [W:] The domestic dog. Its evolution, behavior and interactions with people. SERPELL J. (red.). Cambridge University Press, Cambridge, 119-132.

HART L. A., YAMAMOTO M., 2016. Dogs as helping partners and companions for humans. [W:] The domestic dog. Its evolution, behavior and interactions with people. SERPELL J. (red.). Cambridge University Press, Cambridge, 247270.

HuBRECHT R., WICKENS S., KIRKWOOD J., 2016. The welfare of dogs in human care. [W:] The domestic dog. Its evolution, behavior and interactions with people. SERPELL J. (red.). Cambridge University Press, Cambridge, 271-299.

KALETA T., 2015. Psy poza kontrola jako problem globalny. Życie Wet. 90, 715-720.

LARSON G., KARLSSON E., PERRI A., Webster M. T., Ho S. Y. W., Peters J., Stahl P. W. i współaut., 2012. Rethinking dog domestication by integrating genetics, archeology, and biogeography. Proc. Natl. Acad. Sci. 109, 88788883.

LORD K., SCHNEIDER R. A., COPPINGER R., 2016. Evolution of working dogs. [W:] The domestic dog. Its evolution, behavior and interactions with people. SERPELL J. (red.). Cambridge University Press, Cambridge, 43-66.

MiKLósI A., 2007. Dog behaviour, evolution, and cognition. Oxford University Press, Oxford. 
MONKIEwICZ J., Rogowska K., WAJDZIK J., 2011. Kynologia. Wiedza o psie. Wydawnictwo Uniwersytetu Przyrodniczego, Wrocław.

MOREY D. F., 1986. Studies on Amerindian dogs: taxonomic analysis of canid crania from the Northern Plains. J. Archaeol. Sci. 13, 119145.

MOREY D. F., 1992. Size, shape and development in the evolution of the domestic dog. J. Archaeol. Sci. 19, 181-204.

MOREY D. F., 2006. Burying key evidence: the social bond between dogs and people. J. Archaeol. Sci. 33, 158-175.

MOREY D. F., 2014. In search of paleolithic dogs: a quest with mixed results. J. Archaeol. Sci. 52, 300-307.

NAGASAWA M., Murai K., Mogi K., KiKusui T., 2011. Dog can discriminate human smiling faces from blank expressions. Animal Cognit. $14,525-533$.

NAGasawa M., Mitsui S., En S., OHTANi N., OHTA M., SAKUMA Y., ONAKA T., MOGI K., KIKUSUI T., 2015. Oxytocin-gaze positive loop and the coevolution of human-dog bonds. Science 348 , 333-336.

Olsen S. J., Olsen J. W., 1977. The Chinese wolf, ancestor of New World dogs. Science 197, 533-535.

Ovodov N. D., CROCKFORD S. J., KuZMin Y. V., Higham T. F. G., Hodgins G. W. L., VAN DER PLICHT J., 2011. A 33,000-year-old incipient dog from the Altai Mountains of Siberia: evi dence of the earliest domestication disrupted by the Last Glacial Maximum. PLoS One 6, e22821.

Parker H. G., Kim L. V., SutTer N. B., CARlson S., LORENTZEN T. D., MALEK T. B., JOHNSON G. S., Defrance H. B., Ostrander E. A., KRUGLYAK L., 2004. Genetic structure of the purebred domestic dog. Science 304, 11601164.

PARKer H. G., Vonholdt B. M., Quignon P., MARGulies E. H., ShaO S., Mosher D. S., SPADY T. C. i współaut., 2009. An expressed fgf4 retrogene is associated with breed-defining chondrodysplasia in domestic dogs. Science 325, 995-998.

PERIN C., 1981. Dogs as symbols in human de velopment. [W:] Interrelations between people and pets. FOGLE B. (red.). Charles C. Thomas, springfield, 68-88.

PIONNIER-CAPITAN M., 2010. La domestication du chien en Eurasie: étude de la diversité passée, approaches ostéoarchéologiques, morphométriques et paléogénétiques. Ecole normale supérieure, Lyon; praca doktorska.

Pionnier-CAPITAN M., Bemilli C., Bodu P., CÉlériER G., FERrié J.-G., Fosse P., Garcià M., VIGNE J.-D., 2011. New evidence for Upper Palaeolithic small domestic dogs in South-Western Europe. J. Archaeol. Sci. 38, 2123-2140.

RANGE F., VIRÁNYI Z., 2016. Social cognition and emotions underlying dog behavior. [W:] The domestic dog. Its evolution, behavior and interactions with people. SERPELL J. (red.). Cambridge University Press, Cambridge, 182-209.

SAVOLAINEN P., ZHANG Y., LUO J., LUNDEBERG J., LEITNER T., 2002. Genetic evidence for an East Asian origin of domestic dogs. Science 298, 1610-1613.
SCHASSBURGER R. M., 1987. Wolf vocalizations: an integrated model of structure, motivation and ontogeny. [W:] FRANK H. (red.). Man and wolf: advances, issues, and problems in captive wolf research. Dr W. Junk Publishers, Dordrecht.

ScotT J. P., Fuller J. L., 1965. Genetics and the social behavior of the dog. The University of Chicago Press, Chicago.

SERPELl J., 2016a. The domestic dog. Its evolution, behavior and interactions with people. Cambridge University Press, Cambridge.

SERPELL J., 2016b. From paragon to pariah: cross-cultural perspectives on attitudes to dogs. [W:] SERPELL J. (red.). The domestic dog. Its evolution, behavior and interactions with people. Cambridge University Press, Cambridge, 300-315.

SERPELl J. A., HSU Y., 2005. Effects of breed, sex, and neuter status on trainability in dogs. Anthrozoos 18, 196-207.

SKOGLUND P., ERSMARK E., PALKOPOULOU E., DALÉN L., 2015. Ancient wolf genome reveals an early divergence of domestic dog ancestors and admixture into high-latitude breeds. Curr. Biol. 25, 1515-1519.

StOCKHAUS K.,1965. Metrische Untersuchungen an Schädeln von Wölfen und Hunden. J. Zool. Sys. Evol. Res. 3, 157-258.

Thalmann O., SHAPIRO B., Cui P., SchuenemanN V. J., SAWyer S. K., Greenfield D. L., GerMONPRÉ M. B. i współaut., 2013. Complete mitochondrial genomes of ancient canids suggest a European origin of domestic dogs. Science 342, 871-874.

TCHERNOV E., HORWITZ L. K., 1991. Body size diminution under domestication: unconscious selection in primeval domesticates. J. Anthropol. Archaeol. 10, 54-75.

TRUT L., Oskina I., Kharlamova A., 2009. Animal evolution during domestication: the domesticated fox as a model. BioEssays 31, 349-360.

VAN DEN BERG L., 2016. Genetics of dog behavior. [W:] SERPELL J. (red.). The domestic dog. Its evolution, behavior and interactions with people. Cambridge University Press, Cambridge, 69-92.

Vilà C., Savolainen P., Maldonado J. E., AMORIM I. R., RICE J. E., 1997. Multiple and ancient origins of the domestic dog. Science 276, 1687-1689.

VONHOLDT B. M., POLlinger J. P., LOHMUELleR K. E., HAN E., PARKER H. G., QUiGNON P., DEGENHARDT J. D. i współaut., 2010. Genome-wide SNP and haplotype analyses reveal a rich history underlying dog domestication. Nature 464, 898-902.

WAYNE R. K., 1986. Cranial morphology of domestic and wild canids: the influence of development on morphological change. Evolution 40, 243-261.

WilcoX B., WalKowicz C., 1995. The atlas of dog breeds of the world. T.F.H. Publications, Neptune City.

ZAWISTOWSKI S., REID P., 2016. Dogs in today's socjety: the role of applied animal behavior. [W:] SERPELL J. (red.). The domestic dog. Its evolution, behavior and interactions with people. Cambridge University Press, Cambridge, 227-244. 
KOSMOS Vol. 68, 1, 65-73, 2019

Kamila Plis, JoAnNa STOJAK

Mammal Research Institute PAS, Stoczek 1, 17-230 Białowieża, E-mail: kplis@ibs.bialowieza.pl

DOG DOMESTICATION PROCESS: AN ATTEMPT TO UNRAVEL MYSTERY OF THE SPECIES DOMESTICATION

Summary

Dog is the first animal species domesticated by humans. However, a review of recent studies proves that time and place of its domestication are still unknown. The aim of this article is to familiarize the readers with a probable course of the process of dog domestication and to present its plausible reasons and consequences.

Key words: behavioral traits, Canis lupus familiaris, centers of domestication, morphological traits 